\title{
On travails and perspectives: the future of JoCI
}

\section{Eduardo Villanueva- Mansilla}

\author{
Editor in Chief, The Journal of Community \\ Informatics \\ Corresponding Author. \\ evillan@gmail.com
}

After many months, the Journal of Community Informatics starts publishing its 14th volume. A number of situations forced us to take a longer-than expected break, but now it is time to catch up and bring the Journal into action, again.

Anyone who has tried to publish academic works is well aware of the issues that such endeavor implies. In JoCI's case, there are a number of extras to contend with: an independent publication, not affiliated to - though supported by - academic institutions, with the mission of promoting engagement with a specific issue from both international academia and community practitioners and activists. In a world where it is increasingly difficult to find university researchers not being pressured to publish in the rather constrictive parameters of the academic publication business; and where activistas and practitioners are under various stresses and demand that make even harder to have the time to reflect and write; it is not surprising that supporting a journal like this is not the easiest task.

From the perspective of the editorial team, this also means trying to find readers and writers, supporting them and trying, though failing in some instances, to keep an orderly and predictable publication schedule. A combination of factors made impossible to publish issues of the 14th volume till we are far into the corresponding chronological year. Having managed to fix those factors, the coming months still present the challenge of keeping collaborators engaged: reviewers are, as usual, in sore demand; production of the issues require dedication from a small group of people.

Villanueva-Mansilla, E. (2018). On travails and perspectives: the future of JoCl. The Journal of Community Informatics, 13(4), 1--3.

Date submitted: 2018-10-28. Date accepted: 2018-11-11.

Copyright (C), 2018 (the author as stated). Licensed under the Creative Commons AttributionNonCommercial-ShareAlike 2.5. Available at: www.ci-journal.net/index.php/ciej/article/view/1375 . 
We intend to keep the Journal going. But there are a number of questions that need to be addressed, such as:

1. The appropriation and domestication of ICTD / digital media at the individual level, turning any discussion of "development" almost moot, as the big thrust is basically state policy rather than community (however you define it). The locus of innovation and the locus of policy are basically the same: corporate innovation for individual gratification. Is there anything left for a middle ground? I would think that schools, community organizations (including trade unions and work based associations) and perhaps communities of practice. Not much more.

2. Policy angle: Data driven innovation demands a data justice discussion on how to deal with the issues of surveillance, monetization, and generally speaking work transformation. Fragmentation of the work market destroys solidarities and empowers conglomerates, and the "gig economy" is terrible, again, for organic solidarities. How the data justice paradigm may help.

3. The technical side: how to deal with the larger issues of user and community control of the technology as such, when everything appears to be in the hands of the user but really is just an extension of corporate power? How the interstices and/or the fringe allow for technological innovation or at least resistance at the technological side? Piracy versus submission, so to speak: the kid that download from the Pirate Bay now pays 5 USD a month for Spotify. Of course, my main interest is how the nation state deals with this, but that a whole different ball game.

4. The academic / professional side: CI/DI has always been a loose affiliation of different profesional traditions, InfoSys, CompSci, PolSci, MediaStudies, Sociology/Anthropology/Geography, and of course LIS/Archives. The CI Journal and the Prato conferences were sort of a connective tissue, at a simpler level than the more pretentious ICTD conference or the formal journals (ITID, for instance). How to guarantee, if at all possible, their survival? Does it make sense to maintain them, or it is just a legacy to archive? We need to look beyond our immediate concerns and think about long term viability.

Is it possible to turn JoCI into a journal for these emerging themes, in these confusing times? Is there a long term for our approach? Quite difficult to know, indeed; but the fact is, this assortment of academics, professionals, activists and practitioners that have gathered around JoCI for almost 15 years require a venue; the incoming groups do need that, as well.

With the participation of all interested parties, and the specific support of the University of Kentucky's School of Information Science for technical and hosting matters, our Journal, and specifically the editorial team, intend to continue to strive towards that goal, since amid these transformations, the duty of a Journal like JoCI is to keep up with the new issues and subjects, and to promote new approaches to the main concerns that originally sustained the field. As with some of our previous publications, subjects like 
archival practices, re-conceptualizations of community, emerging practices, and the intersection of computing science / systems analysis and communities are to be of interest.

Our current issue is a great example of our search for new approaches. Thanks to the interest and hard work by Luke Hespanhol, guest editor of this special issue, the intersection between the old (systems and HCI design) and the new (the digital fringe, understood as those that are not catered to by the mainstream services predominant on the Internet) is addressed in a collection of papers that present a very different set of themes, but in the spirit that convened the Journal back in the past decade. It may be the case that the future lies in new perspectives; if so, issues like this one should serve as a gateway to it.

Let me finish by thanking again the great work by our Editorial Team, and the commitment to supporting the Journal from the University of Kentucky. I would like also to thanks Vancouver Community Network, our original and longtime host, for their help. And again, let me thank you, the committed reader of JoCI, for your past and future support: that makes the travails worthwhile. 